\title{
PEMBUATAN GULA CAIR DARI PATI SINGKONG DENGAN MENGGUNAKAN HIDROLISIS ENZIMATIS
}

\author{
Ayu Ratna P, Fitria Yulistiani \\ Jurusan Teknik Kimia, Politeknik Negeri Bandung, Kotak Pos 1234 \\ Email: ayu.ratna@polban.ac.id
}

\begin{abstract}
ABSTRAK.
Pada penelitian ini dibuat gula cair dari tepung tapioka yang dihidrolisis dengan enzim. Hidrolisis enzimatis pati terdiri dari dua tahapan yaitu liquifikasi dan sakarifikasi. Pada proses liquifikasi digunakan enzim $\alpha$-amilase untuk memecah pati yang mengandung amilosa dan amilopektin menjadi dekstrin. Selanjutnya pada tahapan kedua proses sakarifikasi, dimana dekstrin dihidolisa menjadi glukosa dengan bantuan enzim glukoamilase. Volume enzim cair yang ditambahkan adalah 0,$3 ; 0,4$; dan $0,5 \mathrm{ml}$ sedangkan konsentrasi substrat divariasikan $25 \%$; $33,3 \%$; dan $40 \%$. Hasil terbaik diperoleh pada konsentrasi substrat $33,3 \%$ dan volume enzim sebesar $0,3 \mathrm{ml}$, yaitu memiliki kecepatan hidrolisis yang paling cepat untuk proses liquifikasi dan sakarifikasi.
\end{abstract}

Kata Kunci. hidrolisis, enzim, liquifikasi, sakarifikasi, pati

\section{PENDAHULUAN}

Industri makanan dan minuman saat ini sedang berkembang dengan pesat, dimana banyak sekali industri makanan yang mulai mengkreasikan produk mereka sehingga lebih menarik dan mampu menarik minat masyarakat. Misalnya industri roti (bakery) yang dahulu hanya memproduksi roti biasa saja, saat ini mulai banyak berinovasi dengan penambahan aksesoris seperti topping dari gula yang berwarna-warni, cokelat, dan lain sebagainya untuk mempercantik produk roti tersebut.

Tampilan-tampilan cantik dari rotiroti tersebut umumnya banyak menggunakan bahan yang dipadukan dengan gula cair. Industri makanan dan minuman mulai banyak menggunakan gula cair karena memiliki beberapa kelebihan antara lain gula cair tidak mengkristal, lebih mudah diproses karena lebih mudah larut, lebih praktis, dan memiliki tampilan yang lebih menarik jika dibandingkan dengan gula pasir pada umumnya. Permintaan pasar akan gula cair yang tinggi membuat angka impor gula cair semakin tinggi pula sehingga diharapkan Indonesia mampu menyuplai kebutuhan gula cair tersebut tanpa harus melakukan impor, mengingat bahan baku gula cair adalah pati yang mana banyak sekali terdapat di alam Indonesia seperti tapioka (singkong), sagu, pati jagung, dan pati umbi-umbian seperti ubi jalar.

Pada penelitian ini dibuat gula cair dengan menggunakan bahan baku dari pati tapioka. Tepung tapioka dibuat dari hasil penggilingan ubi kayu yang dibuang ampasnya. Ubi kayu tergolong polisakarida yang mengandung pati dengan kandungan amilopektin yang tinggi tetapi lebih rendah daripada ketan yaitu amilopektin $83 \%$ dan amilosa 17\% (Winarno, 2004). Pati merupakan homopolimer glukosa dengan ikatan $\alpha$-glikosidik. Berbagai macam pati tidak sama sifatnya, tergantung dari panjang rantai C-nya serta lurus atau bercabang rantai molekulnya. Pati terdiri dari 2 fraksi yang dapat dipisahkan dengan air panas. Fraksi terlarut disebut amilosa dan fraksi yang tidak larut disebut amilopektin (Risnoyatiningsih, 2011). Amilosa merupakan suatu polimer rantai tunggal tidak bercabang, terbentuk dari 500-20.000 monomer $\alpha$-D-glukosa yang dihubungkan oleh ikatan $\alpha-1,4$ glikosidik. Sedangkan amilopektin adalah suatu polimer rantai bercabang terbentuk dari 100.000 monomer glukosa yang dihubungkan oleh ikatan $\alpha-1,4$ glikosidik pada rantai utama dan $\alpha-1,6$ glikosidik pada percabangannya 
(Kunamneni, 2005).

Pembuatan gula cair pada penelitian ini berbahan baku tepung tapioka dengan proses hidrolisis menggunakan enzim $\alpha$ amilase dan glukoamilase, selanjutnya dalam hidrolisis ini akan ditentukan volume enzim terbaik yang ditambahkan sehingga menghasilkan proses hidrolisis paling cepat. Hidrolisis adalah dekomposisi kimia menggunakan bantuan air untuk memisahkan ikatan kimia dari substansinya. Sedangkan hidrolisis pati adalah proses pemecahan molekul amilum menjadi bagian-bagian penyusun amilum yang lebih sederhana seperti dekstrin, isomaltosa, maltosa dan glukosa (Terahara, 2004).

Hidrolisis pati terdiri atas liquifikasi dan sakarifikasi. Liquifikasi merupakan proses pencairan gel pati untuk memperoleh viskositas yang lebih rendah dengan cara menghidrolisis pati menjadi molekulmolekul yang lebih sederhana yaitu oligosakarida atau dekstrin melalui bantuan enzim $\alpha$-amilase. Proses ini diawali dengan gelatinisasi pati atau pemanasan granula pati dengan air hingga mengembang dan rusak. Suhu pada gelatinasi diatur pada kisaran 66C, sehingga pati dapat terlarut yang ditandai dengan menurunnya viskositas larutan. Sakarifikasi adalah ketika dekstrin hasil liquifikasi akan dihidrolisis lebih lanjut oleh enzim tunggal (glukoamilase) maupun enzim campuran (glukoamilase dan pullulanase) yang biasa disebut dextrozyme untuk dikonversi menjadi glukosa (Ruiz, 2011).

Robi'a (2015) dalam studi kajian pustakanya, mengutip reaksi (a)liquifikasi dan (b)sakarifikasi dari Whitacker (1996).

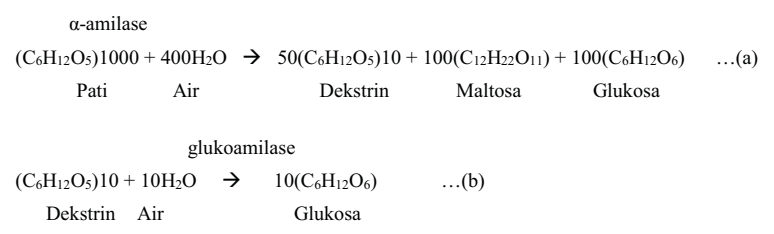

\section{METODE}

Pada penelitian ini digunakan variasi konsentrasi pati yaitu $25 \%$; $33,3 \%$; dan $40 \%$ $(\mathrm{w} / \mathrm{v})$, dimana pada substrat $33,3 \%$ digunakan variasi volume enzim cair yaitu 0,$3 ; 0,4$; serta $0,5 \mathrm{ml}$. Proses pembuatan gula cair ini ada 2 tahapan utama yaitu proses hidrolisis pati dan pemurnian gula cair. Hidrolisis pati yang meliputi proses gelatinasi, liquifikasi, sakarifikasi, sedangkan pemurnian gula cair, meliputi pemucatan, penyaringan, serta penguapan atau pemekatan.

\section{HIDROLISIS}

Tahapan hidrolisis pati yang pertama adalah liquifikasi. Proses dimulai dengan membuat suspensi pati sebagai substrat sebanyak $150 \mathrm{ml}$ dengan variasi konsentrasi yaitu $25 \%, 33,3 \%$, dan $40 \%$. Selanjutnya substrat dipanaskan hingga suhu 60C sebagai proses gelatinasi. Setelah proses gelatinasi dilanjutkan dengan dekstrinasi yaitu penambahan enzim $\alpha$-amilase sesuai dengan variasi konsentrasi. Kondisi operasi diatur pada suhu 90C dan $\mathrm{pH} 6-6,4$ dengan menambahkan kapur tohor jika diperlukan. Pada tahapan ini substrat akan menjadi encer. Proses liquifikasi dihentikan ketika substrat menjadi benar-benar cair dan berwarna coklat bening. Suhu larutan kemudian diturunkan hingga 60C.

Selanjutnya dilakukan sakarifikasi, yaitu substrat dengan suhu 60C ditambahkan enzim glukoamilase dengan perbandingan yang sama terhadap enzim $\alpha$-amilase yang digunakan sebelumnya. Suhu larutan substrat dipertahankan 60C sambil terus diaduk dan proses dihentikan ketika larutan substrat telah mencapai nilai kekentalan 30\%-35\% Brix.

\section{PEMURNIAN GULA CAIR}

Proses pemurnian gula cair ada 3 tahapan, yang pertama yaitu pemucatan. Larutan hidrolisat dicampurkan dengan sedikit arang aktif dan dipanaskan hingga suhu 80C selama 15 menit. Tahapan kedua adalah penyaringan. Campuran substrat dan arang aktif selanjutnya disaring hingga diperoleh filtrat berwarna kuning muda. Tahapan yang ketiga adalah penguapan atau 
pemekatan filtrat dengan cara memanaskan hingga suhu $70 \mathrm{C}$ dan diperoleh filtrat atau gula cair yang lebih kental dengan Brix antara $43 \%-80 \%$.

\section{ANALISIS}

Analisis yang dilakukan adalah secara kualitatif yaitu uji amilum, uji dekstrin, dan uji kandungan glukosa (Benedict) serta secara kuantitatif dengan menganalisis nilai Brix yang dihasilkan selama waktu hidrolisis.

Uji Amilum: Suspensi pati pada proses gelatinasi dianalisis keberadaan amilumnya dengan cara diteteskan cairan lugol. Terjadinya prubahan warna dari putih menjadi biru tua menandakan adanya kandungan amilum pada suspensi pati.

Uji Dekstrin: Uji dekstrin dilakukan untuk mengetahui apakah terbentuk dekstrin pada akhir proses liquifikasi. Suspensi setelah diliquifikasi, ditambahkan dengan lugol dan alkohol pada tabung reaksi secara bertahap.

Uji Benedict: Uji Benedict dilakukan untuk mengetahui apakah ada kandungan glukosa pada produk akhir sakarifikasi. Hasil hidrolisis diteteskan pereaksi Benedict pada tabung reaksi untuk selanjutnya dipanaskan diatas penangas air selama 5 menit.

\section{HASILDAN PEMBAHASAN LIQUIFIKASI}

Hidrolisis enzimatis pada tepung tapioka ini bertujuan untuk membuat gula cair dari bahan baku pati. Ada dua proses utama yang terjadi yaitu liquifikasi dan sakarifikasi. Pada proses liquifikasi, pati akan dipecah menjadi dekstrin, maltose, dan glukosa. Dekstrin merupakan hasil hidrolisis pati yang tidak sempurna. Proses ini juga melibatkan alkali dan oksidator. Pengurangan panjang rantai tersebut akan menyebabkan perubahan sifat dimana pati yang tidak mudah larut dalam air diubah menjadi dekstrin yang mudah larut. Dekstrin bersifat sangat larut dalam air panas atau dingin, dengan viskositas yang relatif rendah.

Hasil liquifikasi tepung tapioka pada variasi volume $\alpha$-amilase yang ditambahkan diamati dari perubahan nilai Brix pada larutan. Perubahan nilai Brix dalam rentang waktu hidrolisis dapat dilihat pada gambar 1 .

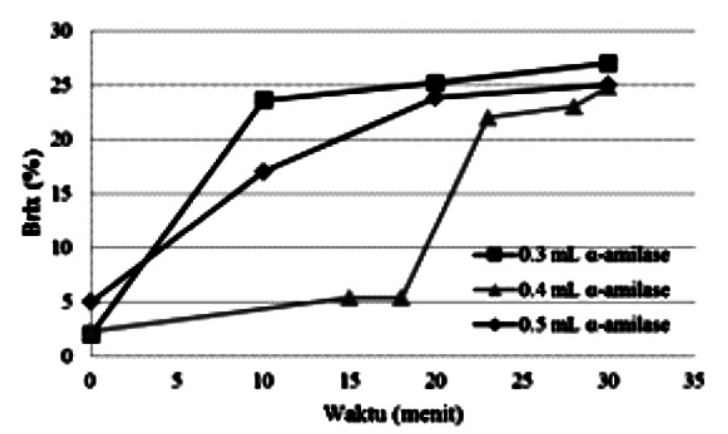

Gambar 1. Gratik hubungan kenaikan Brix selama rentang waktu tertentu dengan variasi volume enzim pada liquifikasi pati singkong

Untuk mengamati pengaruh volume $\alpha$-amilase yang ditambahkan pada proses liquifikasi, gambar 1 diperoleh dengan percobaan menggunakan konsentrasi substrat tetap yaitu $33,3 \%$ sebanyak $150 \mathrm{ml}$, sedangkan volume enzim yang ditambahkan bervariasai yaitu 0,$3 ; 0,4$; dan $0,5 \mathrm{ml}$. Suhu operasi dijaga pada 90C dan sekitar pH 6. Dari gambar 1 dapat dilihat bahwa pada proses liquifikasi dengan penambahan volume enzim $0,3 \mathrm{ml}$ dapat mencapai nilai Brix paling tinggi yaitu $27 \%$ dengan rentang waktu 30 menit. Hal ini menunjukkan bahwa pada kondisi operasi tersebut untuk konsentrasi substrat 33,3\% jumlah enzim yang bekerja optimum adalah 0,3 ml. Peningkatan nilai Brix terjadi secara signifikan pada rentang waktu 0-10 menit proses liquifikasi, sedangkan pada penambahan enzim sebanyak $0,5 \mathrm{ml}$ peningkatan nilai Brix terjadi secara bertahap setiap kenaikan 10 menit. Untuk penambahan enzim sebanyak $0,4 \mathrm{ml}$, kenaikan Brix terjadi sedikit lama hingga mendekati 20 menit baru mengalami kenaikan yang signifikan. Hal ini disebabkan oleh proses gelatinasi yang berlangsung pada kisaran suhu 60-66C belum berlangsung secara maksimal seperti suhu yang kurang tinggi atau terjadi penurunan $\mathrm{pH}$ saat ditambahkan $\alpha$-amilase yang tidak diamati secara seksama sehingga mempengaruhi 
kecepatan proses liquifikasi. Pada menit ke 30 nilai Brix untuk semua larutan dengan variasi volume enzim mendekati nilai yang sama yaitu $25 \%-27 \%$.

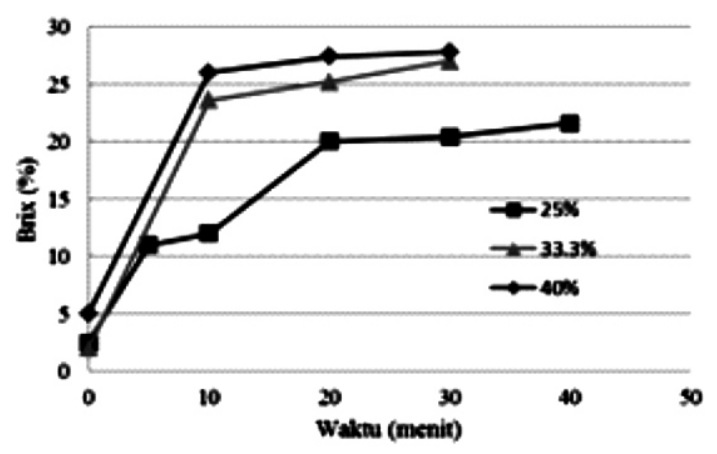

Gambar 2. Grafik hubungan kenaikan Brix selama rentang waktu tertentu dengan variasi konsentrasi substrat pada proses liquifikasi (0,3 $\mathrm{ml} \alpha$-amilase $)$.

Percobaan selanjutnya adalah untuk mengetahui pengaruh konsentrasi substrat dengan volume enzim yang ditambahkan konstan. Konsentrasi substrat divariasikan yaitu 25\%; 33,3\%; dan 40\% dengan volume $\alpha$-amilase yang ditambahkan sebanyak 0,3 $\mathrm{ml}$. Volume enzim ini digunakan karena pada percobaan sebelumnya merupakan kondisi optimum dari proses liquifikasi.

Perubahan nilai Brix terhadap waktu liquifikasi dapat dilihat pada Gambar 2. Pada grafik ini terlihat bahwa konsentrasi substrat $40 \%$ menghasilkan Brix yang paling tinggi yaitu $27,8 \%$. Sedangkan pada konsentrasi substrat 25\% hingga mencapai menit ke 40 perubahan nilai Brix yang terjadi sangat kecil dan cenderung konstan dengan nilai Brix lebih rendah jika dibandingkan pada konsentrasi substrat 33,3\% dan 40\%. Produk yang dihasilkan dari reaksi antara substrat dan enzim dipengaruhi oleh kondisi dari konsentrasi enzim maupun substrat. Pada keadaan konsentrasi enzim meningkat sedangkan konsentrasi substrat tetap, konsentrasi atau jumlah molekul enzim lebih rendah dibandingkan jumlah molekul substrat yang akan dikatalisis, maka produk yang dihasilkan akan sebanding dengan jumlah substrat yang diubah oleh enzim menjadi produk. Bila jumlah enzim ditingkatkan makin banyak substrat yang ada akan diubah menjadi produk hingga suatu ketika jumlah enzim berlebih namun substrat habis. Akibatnya penambahan jumlah enzim tidak akan mengubah grafik kecepatan reaksi vs konsentrasi enzim (Adhiyanto, 2006). Begitu pula dengan perubahan konsentrasi substrat dengan pemberian volume enzim yang konstan, jumlah substrat yang dapat diubah adalah sebanding dengan enzim yang ditambahkan. Dengan demikian pada suatu ketika konsentrasi substrat lebih kecil dan habis terhidrolisis sehingga tidak akan terjadi lagi kenaikan produk untuk setiap kenaikan waktu liquifikasi (nilai Brix konstan setelah rentang waktu tertentu).

\section{SAKARIFIKASI}

Pada tahapan sakarifikasi, suhu larutan diturunkan hingga 60C dan kemudian ditambahkan glukoamilase. Waktu 0 menit sakarifikasi dimulai setelah penambahan glukoamilase. Suhu larutan dijaga konstan dan diamati perubahan nilai Brixnya tiap rentang waktu tertentu. Proses sakarifikasi dihentikan ketika Brix mencapai 30\%-35\%. Kenaikan nilai Brix selama sakarifikasi berlangsung dapat dilihat pada gambar 3 berikut ini.

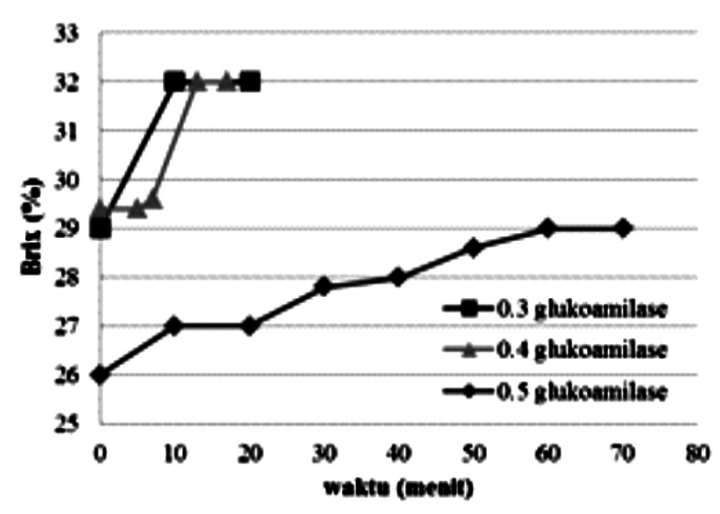

Gambar 3. Grafik hubungan kenaikan Brix selama rentang waktu tertentu dengan variasi volume enzim pada proses Sakarifikasi

Pada gambar 3, terlihat bahwa penambahan 0,3 ml glukoamilase memerlukan waktu paling singkat dan diikuti dengan 
penambahan $0,4 \mathrm{ml}$ glukoamilase untuk mencapai nilai Brix di atas 30\%. Sedangkan larutan dengan penambahan $0,5 \mathrm{ml}$ glukoamilase kenaikan nilai Brixnya lamban dan cukup lama. Pada saat menit ke 70 hanya mampu mencapai nilai Brix 29\%. Hal ini kemungkinan disebabkan awal liquifikasi yang terjadi tidak optimum dan berpengaruh terhadap jumlah dekstrin yang dihasilkan.

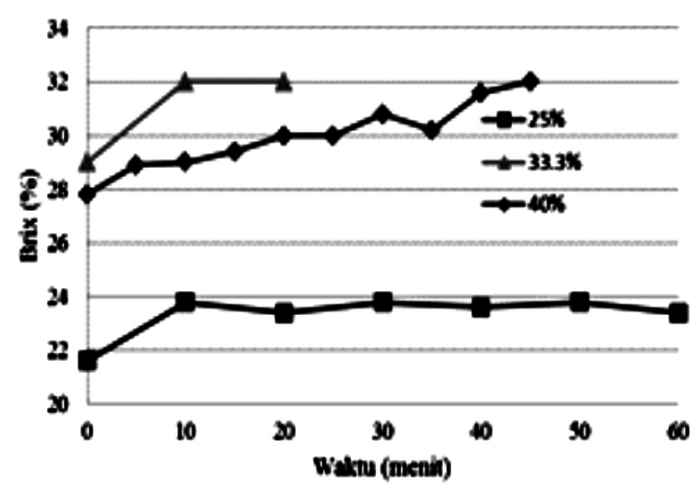

Gambar 4. Grafik hubungan kenaikan Brix selama rentang waktu tertentu dengan variasi konsentrasi substrat pada proses Sakarifikasi (0,3 $\mathrm{ml} \alpha$-amilase)

Percobaan selanjutnya adalah sakarifikasi untuk konsentrasi substrat yang berbeda sedangkan jumlah glukoamilase yang digunakan konstan sebesar $0,3 \mathrm{ml}$, disesuaikan dengan $\alpha$-amilase yang digunakan pada liquifikasi sebelumnya. Gambar 4 menunjukkan bahwa pada substrat $33,3 \%$ mampu mencapai nilai Brix 32\% pada menit ke 10 , dan selanjutnya diikuti dengan substrat $40 \%$ yang mampu mencapai Brix $32 \%$ pada menit ke 45 . Kenaikan Brix terjadi secara bertahap dan lebih lama kemungkinan karena pada substrat $40 \%$ terdapat lebih banyak dekstrin yang akan diubah sedangkan volume glukoamilase yang digunakan konstan yaitu $0,3 \mathrm{ml}$, sehingga sakarifikasi berlangsung lebih lama daripada substrat $30 \%$. Sedangkan untuk substrat $25 \%$, kenaikan nilai Brix tidak terlalu signifikan dan langsung menjadi konstan pada Brix sekitar 23\%. Hal ini dikarenakan jumlah substrat yang dihidrolisis telah habis sehingga produk yang terbentuk konstan setelah rentang waktu tertentu.

\section{HASILANALISIS KUALITATIF}

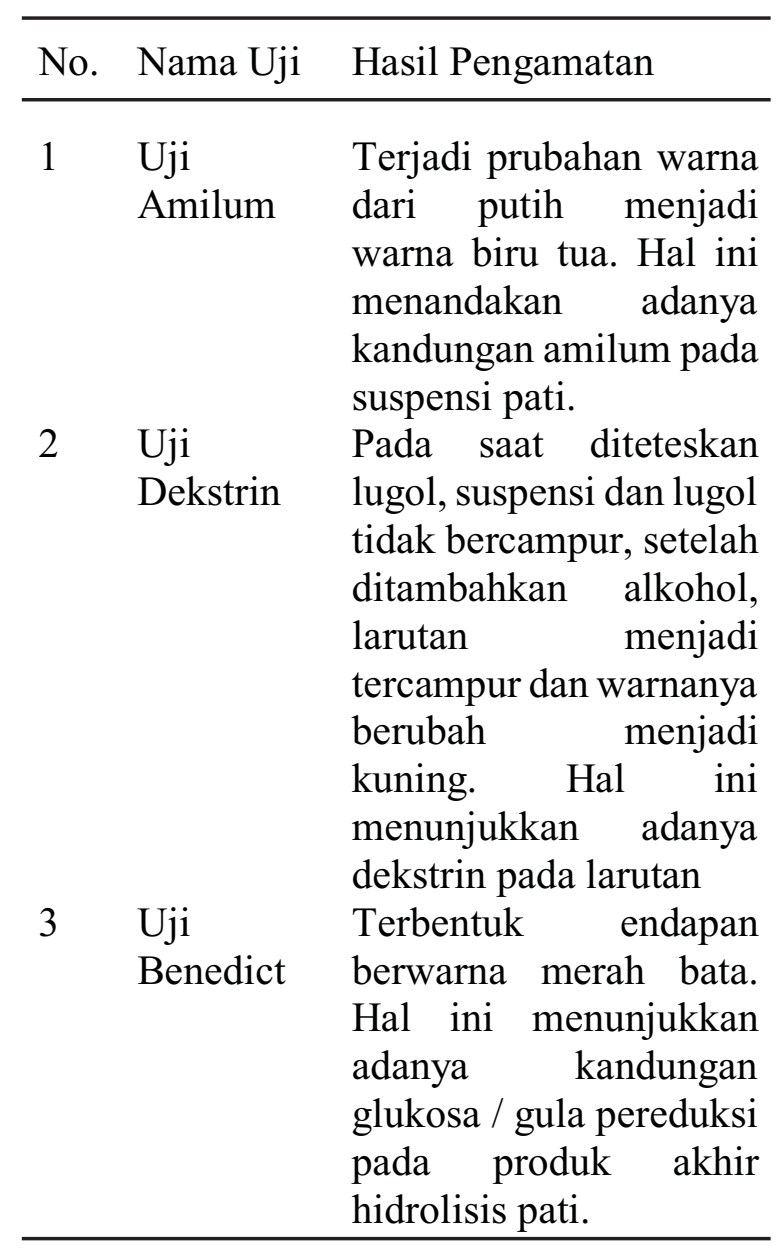

\section{SIMPULAN}

Gula cair dapat dihasilkan dari hidrolisis pati dengan bantuan $\alpha$-amilase dan glukoamilase pada perbandingan 1:1. Kecepatan hidrolisis yang optimum diperoleh pada penambahan volume enzim sebanyak $0,3 \mathrm{ml}$ dengan substrat 33,3\% yaitu sebesar $32 \%$ Brix, dengan total waktu liquifikasi dan sakarifikasi 40 menit. 


\section{DAFTAR RUJUKAN}

Adhiyanto, C., 2006. Pemanfaat Enzim dan Manfaatnya dalam Bidang Biomedik. UIN Press: Jakarta hal 1, hal 115-120.

Kunamneni A.; Permaul K.; dan Singh S. 2005. Amylase production in solid state fermentation by thethermophilic fungus Thermomyces lanuginosus. Journal of Bioscience and Bioengineering 100:2, 168-171.

Risnoyatiningsih, Sri. 2011. Hidrolisis Pati Ubi Jalar Kuning Menjadi Glukosa Secara Enzimatis. UPN Veteran Jawa Timur: Jurnal Teknik Kimia Vol.5, N0.2.

Robi'a; Sutrisno, Aji. 2015. Karakteristik Sirup Glukosa Dari Tepung Ubi Ungu (Kajian Suhu Likuifikasi Dan Konsentrasi A-Amilase): Kajian Pustaka. Jurnal Pangan dan Agroindustri Vol. 3 No 4 p.1531-1537
Ruiz, Monica I.; Shancez, Clara I.; Torres, Rodrigo G.; Molina, Daniel R. 2011. Enzymatic Hydrolysis of Cassava Starch for Production of Bioethanol with a Colombian Wild Yeast Strain. Brazil: J. Braz. Chem. Soc., Vol. 22, No. 12, 2337-2343.

Terahara, N.; Konczak, I.; Ono, H.; Yoshimoto, M.; Yamakawa, O. 2004. Characterization of Acylated Anthocyanins in Callus Induced From Storage Root of Purple-Fleshed Sweet Potato, Ipomoea batatas L. Journal of Biomedicine and Biotechnology. 2004:5. 279-286.

Winarno, F. G., 2004. Kimia Pangan dan Gizi. Cetakan ke-XI. PT. Gramedia Pustaka Utama. Jakarta.

Whitaker, J.R. 1996. Enzymes. Food Chemistry. Thirt Edition. New York: Meracell Dekker, Inc. 